\title{
円形断面放電室をもつ低電カホールスラスタの性能特性とプラズマ状態*1 Performance Characteristics and Plasma Features of Low Power Hall Thrusters with Circular Cross-Sectional Discharge Chambers
}

\author{
白 崎 篤 司*2 ・田原弘 - *2 \\ Atsushi Shirasaki and Hirokazu TAhara
}

\begin{abstract}
Key Words : Electric Propulsion, Hall Thruster, Circular Cross-Sectional Discharge Chamber, Performance, Plasma Features
\end{abstract}

\begin{abstract}
Low power Hall thrusters with circular cross-sectional discharge chambers, named TCHT-series were investigated to obtain the performance characteristics and plasma features. Hall thrusters with circular cross-sectional discharge chambers will be suitable for low power Hall thrusters because of the large volume-to-surface ratio which suppresses overheating of inner magnetic coils and ion losses on the chamber wall. TCHT-2 achieved $25 \%$ of thrust efficiency in the input power range of 100-200 W. From RPA and double probe measurements, it is expected that the ionization region is located near the anode in which strong radial magnetic field exists. The Hall thruster TCHT-3 is downsized thruster for lower power operation, and the effect of magnetic field profiles on thrust performance was examined. TCHT-3 were classified into TCHT-3A and TCHT-3B. The Hall thruster TCHT-3A has the similar magnetic field configuration to TCHT-2, and the peak of radial magnetic flux density is located near the anode. On the other hand, TCHT-3B has the peak of radial magnetic flux density near the thruster exit. Such magnetic profile suppressed the discharge current. However, the specific impulse decreased. As a result, the thrust efficiency of TCHT-3B was lower than that of TCHT-3A. In the input power range of 120-180 W, TCHT-3 achieved higher thrust efficiency than TCHT-2 did. TCHT-series showed that Hall thrusters with circular cross-sectional discharge chambers were suitable for low power Hall thrusters.
\end{abstract}

\section{1. は じめに}

打ち上げコストの削減や開発期間の短縮などの理由から 人工衛星の小型化に注目が集まっている1,2) . ホールスラス 夕は比較的推力密度, 比推力光して推進効率が高く, 小型 衛星用のスラスタとして, 兴の小型・低電力化が行われて きた．しかし，代表的なホールスラスタである Stationary Plasma Thruster (SPT), Thruster with Anode Layer (TAL) と呼ばれるホールスラスタを小型・低電力化する

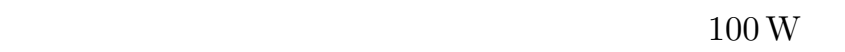
$20 \%$ 未満の推進効率 ${ }^{3,4)}$ ). 第 1 図 (a)，(b) に SPT と TAL の概略図を示す . SPT はセラミックス製の円環状断面の放 電室をもち，TAL は金属製の比較的短い円環状断面の放電 室をもつ.設計相似則 ${ }^{3,5)}$ によりスラスタ寸法が小さくなる に従って大きな磁束密度が必要となる．スラスタ中心に設 置された電磁石用コイル鉄心は細くなるため磁気飽和を生 じて必要な磁束密度が得られなくなる可能性がある . また 小型化とともに放電室に囲まれた中心コイルの冷却が困難 となり, 透磁率が急激に低下する温度まで加熱され，性能 が悪化したという報告もある3).さらに小型化に伴い放電 空間体積に対して放電室表面積か増加するためイオンの壁

\footnotetext{
*1 (C) 2006 日本航空宇宙学会

平成 17 年 9 月 12 日原稿受理

$* 2$ 大阪大学大学院基礎工学研究科機能創成専攻
}

面損失が増大し，性能が低下するという本質的な問題があ る. Raitses らは第 1 図 (c) のような円形断面放電室をもつ ホールスラスタを提案した ${ }^{6,7)}$. このスラスタの放電室断面 は名前の通り円形で SPT , TAL とは異なり，中心コイルは 放電室に囲まれていない，従ってコイル鉄心を太くする空 間的余裕があり，磁気飽和の回避，光して中心コイルへの 入熱の抑制に有効と考えられる．また同じ放電室直径であ れば放電室壁体積/放電室面積比 (以降 Volume-to-Surface ratio : V/S 比と呼ぶ）が SPT と比べて大きく, 小型化に 伴う壁面損失の増加が緩和されると期待される. 弚れゆえ 円形断面放電室をもつホールスラスタは小型・低電力スラ スタとして適していると考えられる．

しかしこのスラスタの設計指針や爫の電離・加速過程 , プ リューム状態等は明らかになっていない，本研究では円形 断面放電室をもつホールスラスタ, TCHT シリーズを用い て作動実験を行い，兴の推進性能とプラズマ特性を調べた． TCHT-2 では陽極位置による性能特性の変化を調べ, さら にプラズマ計測を行い内部の電離・加速過程を推測した .乥 して放電室半径が半分のスラスタ TCHT-3 を製作し，小型 化による性能変化を調べた .

\section{2. 実 験 装 置}

2.1 ホールスラスタ作動システム ホールスラスタの 作動は直径 $1.2 \mathrm{~m}$, 長さ $2.25 \mathrm{~m}$ の真空タンク内で行う ${ }^{8 \sim 11)}$. 


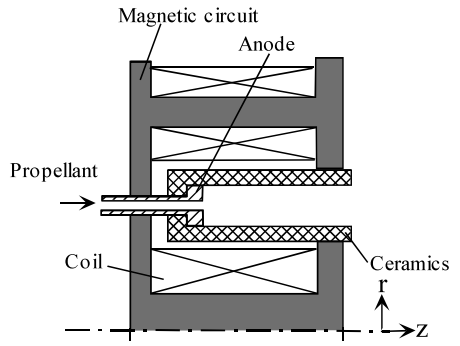

(a) SPT

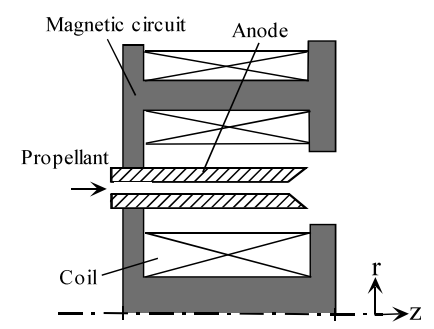

(b) TAL

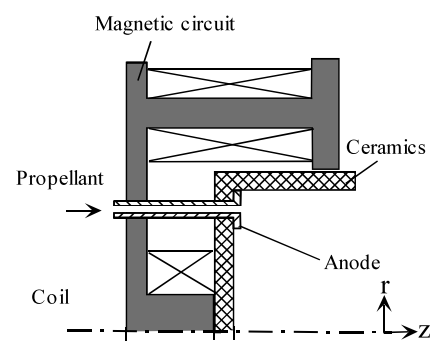

(c) 円形断面放電室をもつホールスラスタ

第 1 図 ホールスラスタの種類

作動時の背圧は推進斉流量 $0.37 \sim 1.0 \mathrm{mg} / \mathrm{s}$ の範囲において $8 \times 10^{-3} \sim 1.6 \times 10^{-2} \mathrm{~Pa}\left(6 \times 10^{-5} \sim 1.2 \times 10^{-4}\right.$ Torr $)$ で ある．陰極にはホロー陰極を用いた，推進阂およびホロー 陰極の作動ガスとしてキセノンを用いた .

2.2 円形断面放電室をもつホールスラスタ TCHT シ リーズ 大阪大学では現在まで円形断面放電室をもつホー ルスラスタの 3 号機までを試作した . 1 号機から 3 号機まで を兴れ光れ TCHT-1，2，3 と呼ぶ. TCHT-1では基礎作動 実験を行い，安定に作動することを確認した $\left.{ }^{9}, 10\right)$. TCHT-2 と TCHT-3 の概略図を第 2 図 (a) , (b) に示す. 光れ光れの 寸法と特徵を第 1 表に示す.表中の $r, L_{1}, L_{2}$ は光れ光れ 放電室半径, 円形断面部の長さ，円環状断面部の長さを表 している . TCHT-2 については円環状断面部の長さ $L_{2}$ を $0 \mathrm{~mm}$ と $10 \mathrm{~mm}$ に変えて性能比較を行った . 円環状断面部 の放電室幅は $8 \mathrm{~mm}$ である.中心コイルと外側コイルによっ て TCHT-2 の放電室内に磁場を形成する . TCHT-2 の放 電室壁材料としてボロンナイトライドセラミックス (Boron Nitride : BN) を用いている.

TCHT-3 は TCHT-2 よりも小型のスラスタで兴の放電 室半径は TCHT-2 の半分の $14 \mathrm{~mm}$ である . また放電室は 円形断面部のみで構成されている．TCHT-3 のスラスタ中 心軸上に永久磁石か設置されている. TCHT-3 は A タイ プと B タイプに分類され，第 2 図 (b)の (*) で示されて

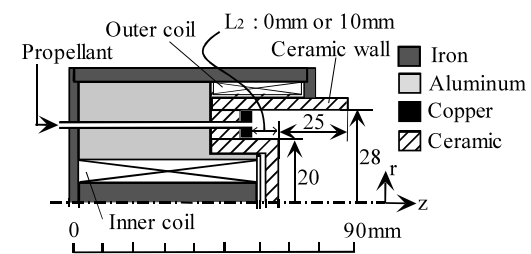

(a) TCHT-2

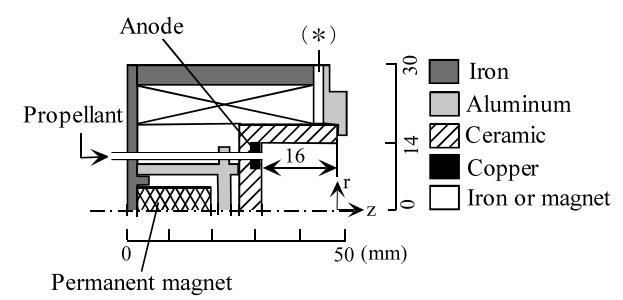

(b) TCHT-3 ( ( *) は永久磁石または, 軟鉄である)

第 2 図 ホールスラスタ TCHT-2, 3 の概略図

\begin{tabular}{lcccc}
\multicolumn{4}{c}{ 第1 表 } & \multicolumn{3}{c}{ ホールスラスタ TCHT-2,3 の寸法と特徵 } \\
\hline & $r$ & $L_{1}$ & $L_{2}$ & 備 考 \\
\hline TCHT-2 & $28 \mathrm{~mm}$ & $25 \mathrm{~mm}$ & $\begin{array}{r}10 \mathrm{~mm} \\
0 \mathrm{~mm}\end{array}$ & 円環状断面部をもつ \\
\hline TCHT-3A & $14 \mathrm{~mm}$ & $16 \mathrm{~mm}$ & & $\begin{array}{l}\text { 外側に電磁石コイルをもつ } \\
\text { リング状永久磁石をもつ }\end{array}$ \\
\hline
\end{tabular}

いる部材か軟鉄である場合を TCHT-3A，リング状の永久 磁石である場合を TCHT-3B と呼ぶ . B タイプの作動時に は外側コイルを用いない . このリング状の磁石はセグメン 卜磁石を 6 個接着してリング状にしたもので内外二極，す なわち径方向に着磁されている. TCHT-3A と TCHT-3B の磁場分布は大きく異なり本研究ではこの二つの場合につ いて推進性能を比較した .

第 3 図にコイル電流比 $1: 1$, コイル電流 $2 \mathrm{~A}$ の場合の TCHT-2 の磁場分布を示す. 第 3 図 (a) に示されている磁 力線形状からノズル状の磁場が形成されていることがわか る.また第 3 図 (b) から TCHT-2 の $L_{2}=10 \mathrm{~mm}$ の場合， 陽極近傍で半径方向磁束密度は極大值をとり，TCHT-2の $L_{2}=0 \mathrm{~mm}$ の場合は放電室出口から陽極に向かうにつれ 半径方向磁束密度は増加する. TCHT-3 の磁場分布につい ては 3.3 節で述べる.

2.3 推力測定 ホールスラスタは振り子式スラストス タンドに設置され作動時のスラスタスタンドの変位が非接 触変位計で測定され推力か評価される ${ }^{8 \sim 10)}$. スラスタには おもりか接続されており，このおもりの個数を真空環境下 でモータと受け皿によって変化させてスラスタに水平方向 の力を負荷する .こうしておもりによる負荷と変位計の出 力信号との関係が得られる.この関係を用いてスラスタ作 動時の変位計出力を推力に変換する.

2.4 プラズマ計測 本研究では静電ダブルプローブ, イ オンコレクタ, 反射電場型エネルギアナライザ (Retarding potential analyzer : RPA) を用いて TCHT-2 放電室内部 と噴出プリュームのプラズマ測定を行った . 


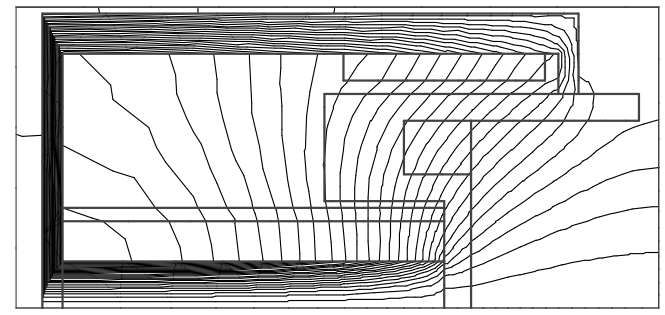

(a) 磁力線分布 (コイル電流比 $1: 1$, コイル電流 $2 \mathrm{~A}$ )

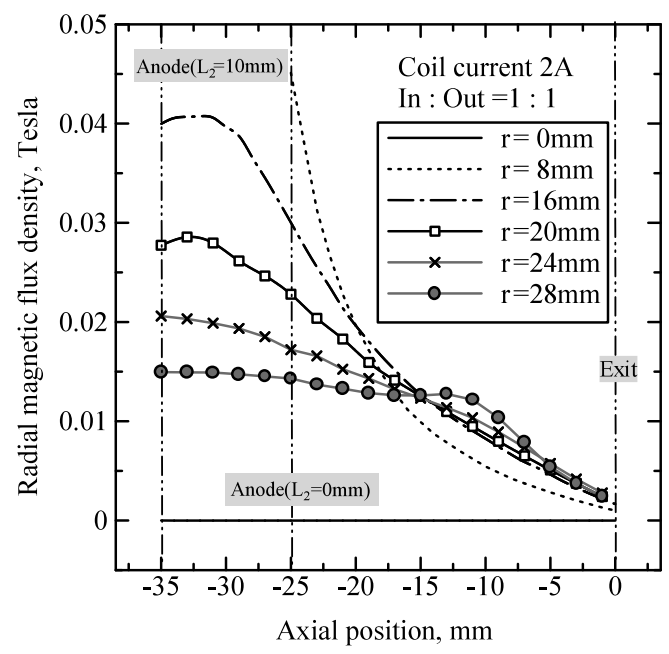

(b) 半径方向磁束密度の軸方向分布

第3 図 TCHT-2 の磁場分布

2.4.1 イオンコレクタ測定 イオン電流測定はイオンコ レクタを用いて行った . イオンコレクタは直径 $20 \mathrm{~mm}$ の捕 集電極と外径 $25 \mathrm{~mm}$ のガードリングで構成されている ${ }^{11)}$. ガードリングと電極との間には $0.5 \mathrm{~mm}$ の隙間か設けられ ている．電極とガードリングには同じ $-27 \mathrm{~V}$ の電圧が印 加されており，ガードリングは電極の端効果を防ぐ役割を 担っている . スラスタ出口から $27.5 \mathrm{~cm}$ 離れた下流にイオ ンコレクタを設置し , スラスタ中心軸上を $0^{\circ}$ として $\pm 90^{\circ}$ の範囲で掃引し，測定を行った 。

2.4.2 RPA 測定 反射電場型エネルギアナライザ (RPA) を用いてイオンエネルギを測定した . RPA は 3 枚 のグリッドと捕集電極から構成されている . 1 枚目のグリッ ドは浮動電位になっており， 2 枚目は $-27 \mathrm{~V}$ の電圧が印加 されている.乥して , 3 枚目のグリッドに正の電圧を掃引 しイオンエネルギ分布を得る. スラスタ出口から $35 \mathrm{~cm}$ 下 流のスラスタ中心軸上に RPA を設置して測定を行った .

2.4 .3 静電ダブルプローブ測定 放電室内の電子温度と 電子数密度を得るためダブルプローブ測定を行った . ダブル プローブ測定システムの概略图を第 4 図に示す . ダブルプ ローブは X-Y ステージ上に設置されたプローブ挿入装置の アームに取り付けられている .プローブ電極にはタングス テン線を用い, プローブ電極の寸法は $\phi 0.4 \mathrm{~mm} \times 5.5 \mathrm{~mm}$ である .プローブ挿入装置によりプローブはスラスタ軸方 向に 2 秒の周期で往復運動する . 往復運動の際 , プローブ が最も陽極側 (上流側) に至った点 (光学センサで検出す

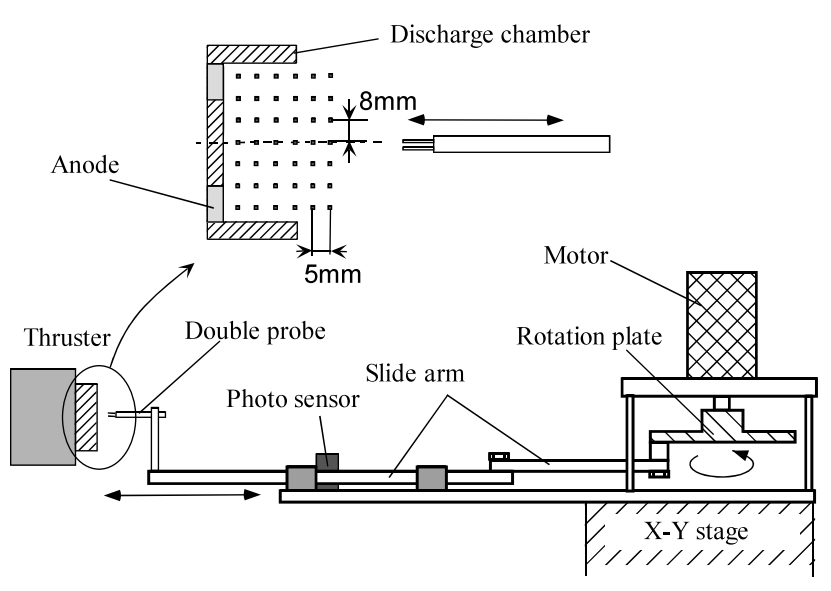

第 4 図＼cjkstart静電ダブルプローブ測定システム

る)におけるプローブ電流ープローブ間電圧特性を計測し， 電子温度と電子数密度を算出する. プローブが放電室内に 留まる時間を短くすることによりプローブの焼損やスラス 夕作動への影響を抑える. 半径方向に $r=-24 \sim 24 \mathrm{~mm}$, 軸方向に $z=-20 \sim 10 \mathrm{~mm}$ の範囲において, 半径方向に $8 \mathrm{~mm}$ 間隔，軸方向に $5 \mathrm{~mm}$ 間隔で測定を行った .

\section{3. 実験結果と考察}

3.1 円形断面放電室をもつホールスラスタの性能特性 TCHT-2 を用いて円環状断面部の有無が推進性能に及ぼ す影響を調べた . 作動の安定性を考慮して円環状断面部を 設けたが, これは SPT と同樣，中心コイルの寸法を制限 するため，本来取り除かれるべきである．乥こで円環状断 面部の長さを $0 \mathrm{~mm}, 10 \mathrm{~mm}$ と変化させて性能比較を行っ た . 円環状断面部をもたない $L_{2}=0 \mathrm{~mm}$ の場合において も安定に作動を行うことができた . 放電電圧は $200 \mathrm{~V}$ ，内 側コイルと外側コイルの電流比は $1: 1$ とし, コイル電流は $0.6 \sim 2.6 \mathrm{~A}$ の範囲で変化させた .

第 5 図は放電電圧を $200 \mathrm{~V}$ に一定にした場合のコイル電 流に対する推進特性の変化を示したものである.第 5 図 (a) の放電電流-コイル電流特性より， $L_{2}=10 \mathrm{~mm}$ の場合，コ イル電流の増加に伴い放電電流は減少し, コイル電流 $1.2 \mathrm{~A}$ 付近で最小の值をとる．乥してコイル電流をさらに増加さ せると放電電流は若干増加し, 弚の後ほぼ一定となる。一 方 $L_{2}=0 \mathrm{~mm}$ の場合はコイル電流の増加とともに放電電 流は減少し, コイル電流 $2 \mathrm{~A}$ 以上ではほほ横ばいとなった . また， $L_{2}=10 \mathrm{~mm}$ の場合のように放電電流の最小值の存 在は確認できなかった . $L_{2}=10 \mathrm{~mm}$ の場合の放電電流は $L_{2}=0 \mathrm{~mm}$ の場合と比べて小さかった .これは円環状断面 部において比較的磁束密度が大きく，電子の陽極への移動 が抑制され放電電流が抑えられたためと考えられる .

第 5 図 (b) は推力・比推力のコイル電流に対する変化を 示している. $L_{2}=10 \mathrm{~mm}$ の場合は $1.2 \mathrm{~A}$ 付近で推力・比 推力が若干減少しているが, $L_{2}=0 \mathrm{~mm}$ の場合はコイル電 流にかかわらずほぼ一定となっている . $L_{2}=10 \mathrm{~mm}$ の場 合で見られる推力・比推力の谷は放電電流が最小になって 


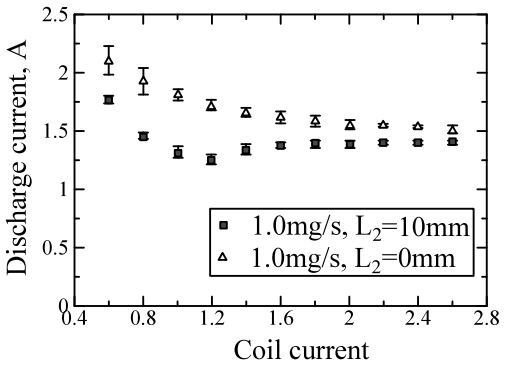

(a) 放電電流

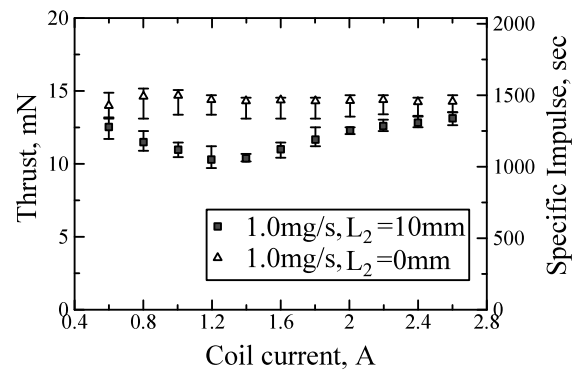

(b) 推力 $\cdot$ 比推力

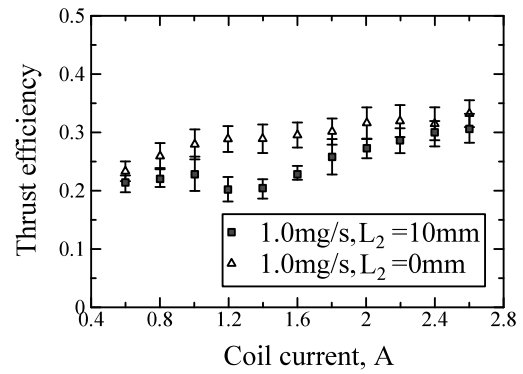

(c) 推進効率

第 5 図 推進特性とコイル電流の関係 $\left(L_{2}=0 \mathrm{~mm}\right.$ と $L_{2}=10 \mathrm{~mm}$ との比較, コイル電流比 $1: 1$, 放電電圧 $200 \mathrm{~V}$, 推進剂流量 $1.0 \mathrm{mg} / \mathrm{s})$

いる箇所に対応しており，このことから何らかの原因で推 進剂利用効率が減少したものと考えられる. $L_{2}=10 \mathrm{~mm}$ の場合の推力・比推力は $L_{2}=0 \mathrm{~mm}$ の場合と比べて小さ かった . $L_{2}=10 \mathrm{~mm}$ の場合, 円環状断面部は狭窄してい るためここで生じたイオンが壁面に衝突し , 推力の損失が $L_{2}=0 \mathrm{~mm}$ の場合に比べて大きくなったためと推察され る.第 5 図 (c) に示すように $L_{2}=10 \mathrm{~mm}$ の場合 , 一部落 ち込む領域が存在するが，いずれのタイプにおいてもコイ ル電流の増加とともに推進効率は増加した . また円環状断 面部をもたない $L_{2}=0 \mathrm{~mm}$ の場合においてより高い推進 効率が得られた .

3.2 円形断面放電室をもつホールスラスタのプラズマ 特性

3.2.1 イオンビーム特性 低電力化するためにはより少 ない流量で作動させる必要がある．TCHT-2 を用い，流量 を $0.5 \mathrm{mg} / \mathrm{s}$ と小さくして作動を行った .この際, 高い推進 効率を考慮して， $L_{2}=0 \mathrm{~mm}$ とした . 放電電圧 $200 \mathrm{~V}$ に おける流量 $0.5 \mathrm{mg} / \mathrm{s}$ と $1.0 \mathrm{mg} / \mathrm{s}$ に対する推進性能を第 2 表に示す $.0 .5 \mathrm{mg} / \mathrm{s}$ の場合, 比推力が低く推進性能が低下
第2 表 ホールスラスタ TCHT-2B の推進性能（推進 剂質量流量 $0.5 \mathrm{mg} / \mathrm{s}$ と $1.0 \mathrm{mg} / \mathrm{s}$ との比較)

\begin{tabular}{lcccc}
\hline & Coil current & $I d$ & $I s p$ & $\eta_{\mathrm{T}}$ \\
\hline $0.5 \mathrm{mg} / \mathrm{s}$ & $2 \mathrm{~A}$ & $0.65 \mathrm{~A}$ & $1200 \mathrm{~s}$ & $27 \%$ \\
$1.0 \mathrm{mg} / \mathrm{s}$ & $2 \mathrm{~A}$ & $1.54 \mathrm{~A}$ & $1450 \mathrm{~s}$ & $31 \%$ \\
\hline
\end{tabular}

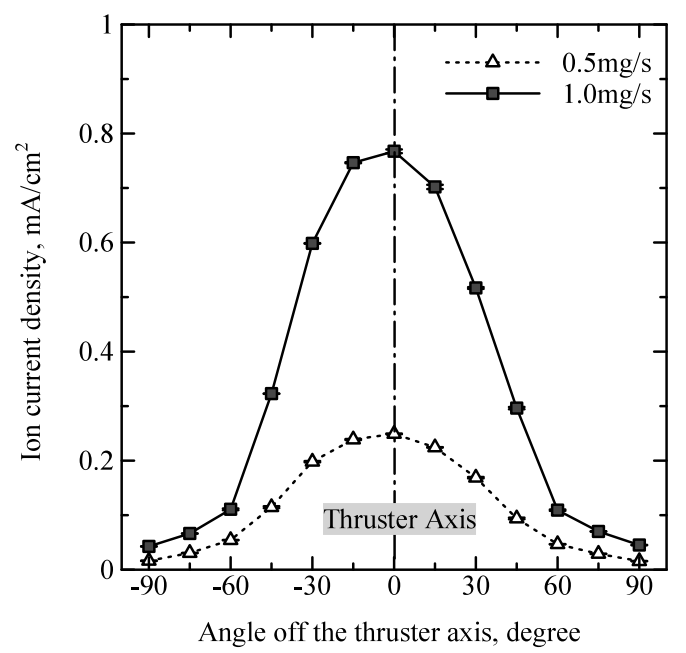

第6図 ホールスラスタ TCHT-2 $\left(L_{2}=0 \mathrm{~mm}\right)$ のイオン電流密度 分布 $(0.5 \mathrm{mg} / \mathrm{s}$ と $1.0 \mathrm{mg} / \mathrm{s}$ との比較, 放電電圧 $200 \mathrm{~V}$, コ イル電流比 $1: 1$, コイル電流 $2 \mathrm{~A}$ )

する.

イオンコレクタで測定した $0.5 \mathrm{mg} / \mathrm{s}$ 及び $1.0 \mathrm{mg} / \mathrm{s}$ にお けるイオン電流分布を第 6 図に示す.全イオン電流の $95 \%$ を 含む半頂角をビーム発散角と定義すると，2つの流量に対す るビーム発散角はいずれも $75^{\circ}$ であつた .すなわちビーム発 散角は流量による影響を受けないことがわかった . $0.5 \mathrm{mg} / \mathrm{s}$ の場合の推進斉利用効率は $0.97,1.0 \mathrm{mg} / \mathrm{s}$ の場合の炎れは 1.3 であった . $1.0 \mathrm{mg} / \mathrm{s}$ の場合に推進剂利用効率が 1 を超 えているのは 2 価イオンの存在に起因するものと推察され る. 定性的には $1.0 \mathrm{mg} / \mathrm{s}$ の場合 $0.5 \mathrm{mg} / \mathrm{s}$ に比べて推進刘 利用効率が高いと考えられる .これは放電室内における中 性粒子密度が $0.5 \mathrm{mg} / \mathrm{s}$ の場合小さく, 電子との衝突・電離 が起こりにくいためと推察される .

RPA で測定したイオンエネルギ分布を第 7 図に示す .い ずれの作動条件においても低エネルギ $(<50 \mathrm{eV})$ において 高いピークが見られる .これは真空タンク内の背景中性粒 子との電荷交換衝突によって生じた低エネルギイオンによ るものと考えられる . 従ってこのピークはスラスタで加速 されたイオンビームによるものではないと推察される . 放 電電圧 $200 \mathrm{~V}$ において $0.5 \mathrm{mg} / \mathrm{s}$ の場合 $174 \mathrm{eV}, 1.0 \mathrm{mg} / \mathrm{s}$ の場合 $187 \mathrm{eV}$ にイオンエネルギのピークが見られる .この ピークは放電電圧によって移動するためスラスタで加速さ れたイオンによるものと考えられる . 放電電圧 $200 \mathrm{~V}$ にお いて 50〜 $300 \mathrm{eV}$ の間でイオンエネルギの平均值を算出す ると $0.5 \mathrm{mg} / \mathrm{s}$ と $1.0 \mathrm{mg} / \mathrm{s}$ の場合光れ光れ $160 \mathrm{eV}, 178 \mathrm{eV}$ であった . $0.5 \mathrm{mg} / \mathrm{s}$ の場合，ピークエネルギと平均エネル ギいずれについても $1.0 \mathrm{mg} / \mathrm{s}$ に比べて若干低い . 他の放電 電圧についても同樣の傾向がある . $0.5 \mathrm{mg} / \mathrm{s}$ の場合放電室 


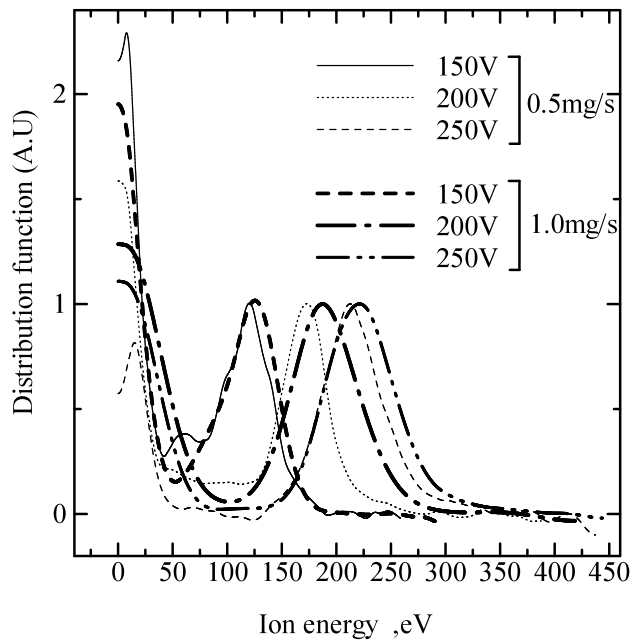

第7图 ホールスラスタ TCHT-2 $\left(L_{2}=0 \mathrm{~mm}\right)$ のイオンエネルギ分 布 $(0.5 \mathrm{mg} / \mathrm{s}$ と $1.0 \mathrm{mg} / \mathrm{s}$ との比較, 放電電圧 $150 \sim 250 \mathrm{~V})$

内の中性粒子・電子数密度が小さいため, 中性粒子が電位の 下がった下流に至るまで電離されずに到達し，電圧利用効率 が若干低下したと考えられる.以上のことから $0.5 \mathrm{mg} / \mathrm{s}$ に おける推進性能の低下は推進剂利用効率と電圧利用効率の 低下によるものであり，これは放電室内における中性粒子 密度の低下に起因するものと推察される.従って $0.5 \mathrm{mg} / \mathrm{s}$ 以下の流量で推進性能を維持するためには放電室の径を小 さくする必要がある .

3.2.2 電子温度. 電子数密度分布 推進性能の更なる向 上のためには電離・加速過程の解明が不可欠であり, 产のた めには放電室内のプラズマ物理量の把握が必要となる . 流 量 $0.5 \mathrm{mg} / \mathrm{s}$, 放電電圧 $200 \mathrm{~V}$ の場合のダブルプローブ測定 より得られた放電室内部の電子数密度と電子温度分布を第 8 図に示す.第 8 図 (a) の電子数密度分布からスラスタ中 心軸上の上流側で電子数密度が高い領域が存在する. これ はノズル磁場に沿って電子が移動し磁力線の収束する箇所 に集中するためと考えられる.第 8 图 (b) に電子温度分布 を示す . 放電室内の電子温度は $8 \sim 20 \mathrm{eV}$ であり, 陽極付近 で高くなっている．陽極付近の電子温度が高いこととイオ ンビームのピークエネルギが放電電圧に近い (放電電圧の 約 90\%) ことから電離・加速は主に陽極近傍の半径方向磁 場の強い箇所で起こっていると考えられる．電離領域が陽 極に近いため生成された電子は容易に陽極に流れ込み，加 速効率 (放電電流に対するイオン電流の割合) の低下を招 き，最高でも $30 \%$ 程度の推進効率しか得られなかったと考 えられる. 従って推進効率の向上のためには電離領域を陽 極から離れた位置に形成する必要があると推察される .

3.3 円形断面放電室をもつホールスラスタの小型化 少 流量作動においても放電室内における電離が十分に行われる ように TCHT-2 よりも放電室半径の小さい小型の TCHT-3 を製作した . TCHT-3 の磁場形状を第 9 図に示す . TCHT$3 \mathrm{~A}$ に関しては第 9 图 (a) に示されるように TCHT-2 と同 樣の磁場が形成されている.一方，TCHT-3B の磁場は第 9 图 (b) , (c)のように TCHT-3A とは大きく異なり，下流

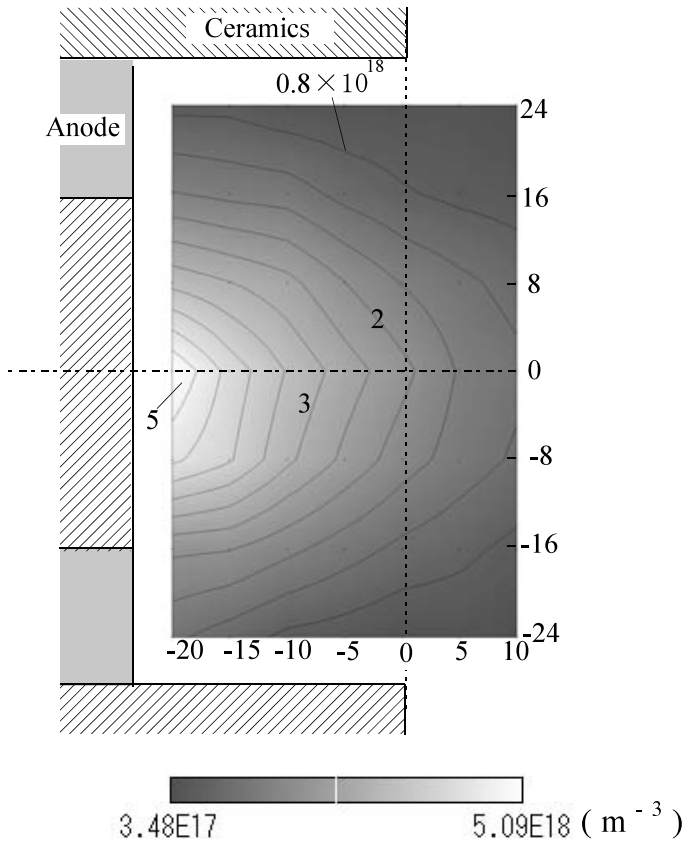

(a) 電子数密度分布

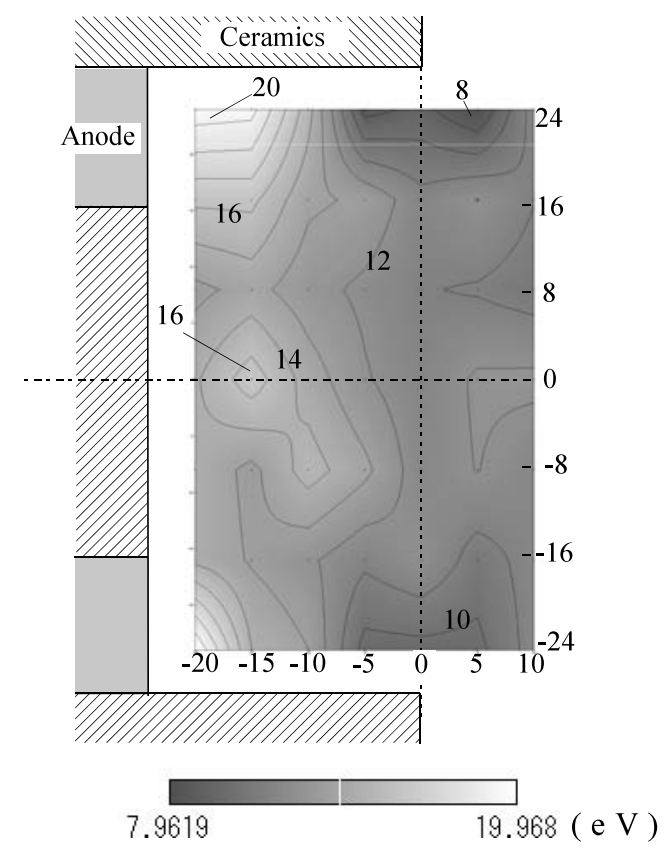

(b) 電子温度分布

第8図 ホールスラスタ TCHT-2 $\left(L_{2}=0 \mathrm{~mm}\right)$ のプラズマ特性 (放 電電圧 $200 \mathrm{~V}$, 推進剂流量 $0.5 \mathrm{mg} / \mathrm{s}$ )

に大きな半径方向磁場が形成されている．

3.3.1 TCHT-3A の基本作動特性 流量 $0.25 \mathrm{mg} / \mathrm{s}$, $0.37 \mathrm{mg} / \mathrm{s}$ 及び $0.5 \mathrm{mg} / \mathrm{s}$ の場合のコイル電流に対する推 進性能の变化を第 10 図に示す.この際, 放電室材質として BN を用いた . 第 10 図 (a)よりいずれの流量に対してもコ イル電流の増加に伴い放電電流は緩やかに減少することが わかる. 第 10 图 (b) の推力・比推力ーコイル電流特性より, コイル電流 $0.4 \mathrm{~A}$ の場合を除いて比推力はコイル電流に対 してほぼ一定となる.コイル電流 $0.4 \mathrm{~A}$ の場合に比推力が 低下するのは電子の磁場による捕捉が不十分で推進剂利用 


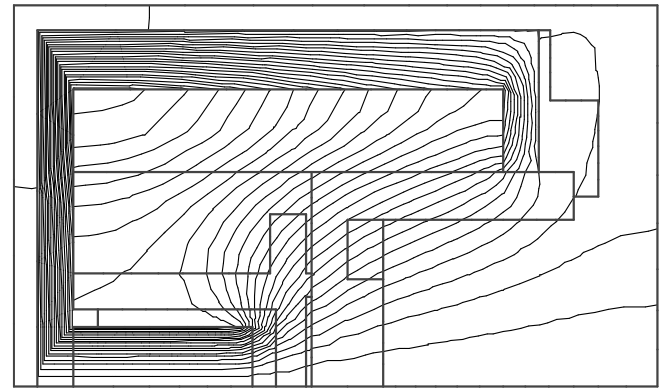

(a) TCHT-3A の磁力線形状（外側コイル電流 $2 \mathrm{~A}$ )

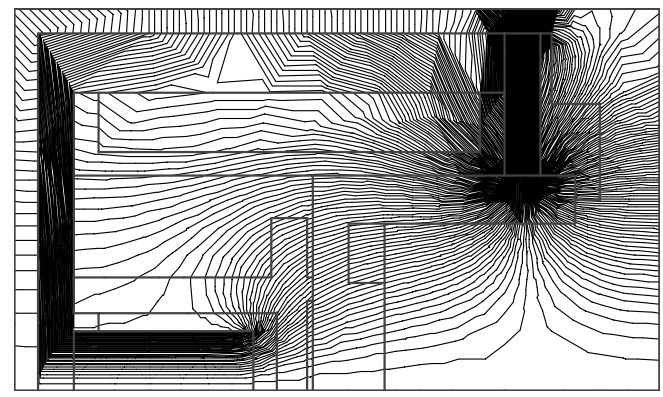

(b) TCHT-3B の磁力線形状

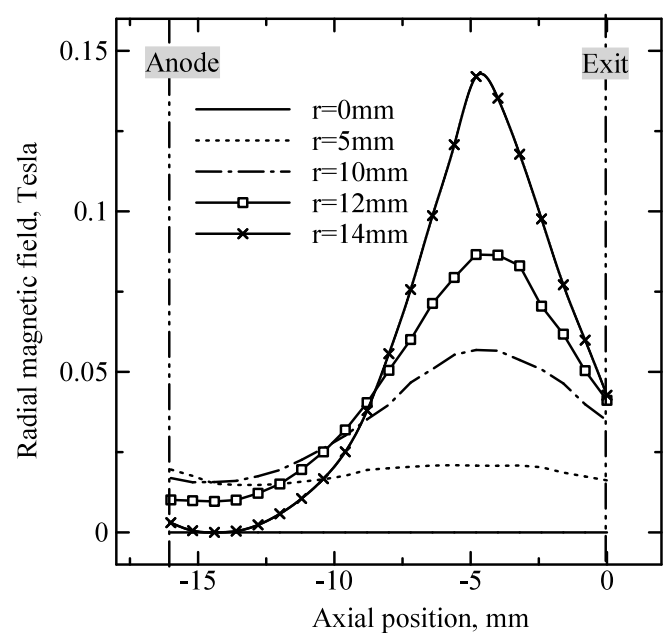

(c) TCHT-3B の半径方向磁束密度の軸方向分布

第 9 図 ホールスラスタ TCHT-3 の磁場分布

効率が低下するためと考えられる $.0 .25 \mathrm{mg} / \mathrm{s}$ の場合に比 推力が他の流量に比へて低い原因は放電室内における中性 粒子密度がさく，推進剂利用効率が低下したためと考え られる. $0.37 \mathrm{mg} / \mathrm{s}$ と $0.5 \mathrm{mg} / \mathrm{s}$ の場合の比推力はいずれも 1200〜 $1300 \mathrm{~s}$ 程度であり，TCHT-2 の $1450 \mathrm{~s}$ には及ばな かった . TCHT-3 の V/S 比は $4.87(\mathrm{~mm})$ ， TCHT-2 の光 れは $8.97(\mathrm{~mm})$ であり, TCHT-3の V/S 比は TCHT-2 に 比べて小さく, $0.5 \mathrm{mg} / \mathrm{s}$ の場合壁面損失か増加したため比 推力が低下したと考えられる $.0 .37 \mathrm{mg} / \mathrm{s}$ の場合, 壁面損失 は $0.5 \mathrm{mg} / \mathrm{s}$ の場合に比べて小さいものの，推進阂利用効率 が低く，結局 $0.5 \mathrm{mg} / \mathrm{s}$ の場合と同程度の比推力にとどまっ たものと推察される. 推進効率一コイル電流特性を第 10 図 (c) に示す . コイル電流の増加とともに推進効率は緩やかに 増加する . 推進効率は $0.37 \mathrm{mg} / \mathrm{s}$ の場合に最も高く, 最高

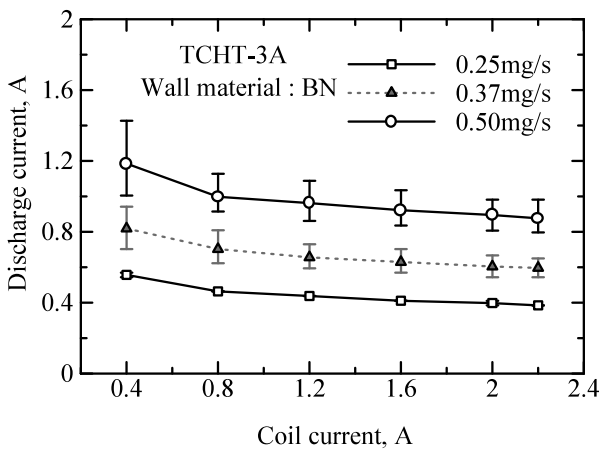

(a) 放電電流

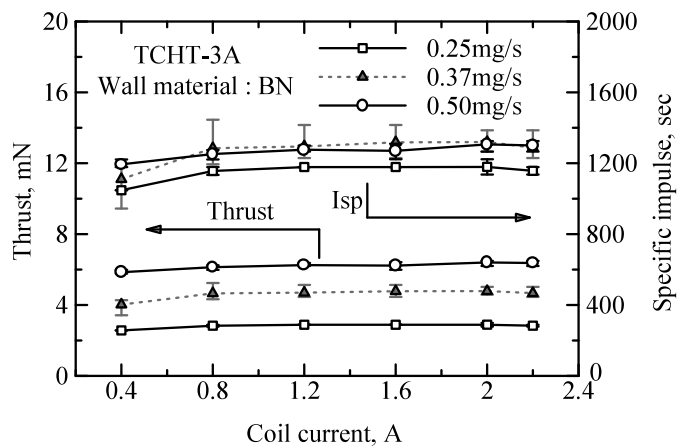

(b) 推力 · 比推力

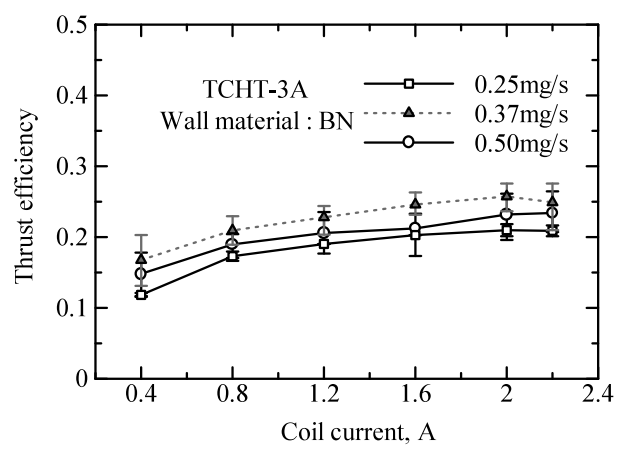

(c) 推進効率

第10図 ホールスラスタ TCHT-3A の推進特性とコイル電流の関係 (放電電圧 $200 \mathrm{~V}$, 推進剂流量 $0.37 \mathrm{mg} / \mathrm{s}$, 放電室材質 $\mathrm{BN}$ )

で $25 \%$ 程度であった .

3.3.2 性能特性に及ぼす磁場分布の影響 円形断面放電 室をもつホールスラスタの推進効率の向上には加速効率の 向上が必要であり，产のためには電離領域を陽極から離れ た下流に形成する必要がある．またこうすることにより壁 面損失を低減することも期待できる．先に述べたように， 電離領域は半径方向磁束密度が大きい箇所に形成されると 予想される。乥こで，リング状永久磁石を用いた TCHT3B を製作し，下流域に大きな半径方向磁場を印加すること により，電離領域を下流に形成することを試みた，光して TCHT-3A と 3B の性能比較を行った .この際，放電室壁 材質として BNAlN (Boron Nitride-Aluminum Nitride) を用いた ここれは BNAlN を用いた場合，推進効率はBN の場合とほぼ同等でより高い比推力を得られたためである． 流量 $0.37 \mathrm{mg} / \mathrm{s}$ と $0.5 \mathrm{mg} / \mathrm{s}$ で作動を行ったが, $0.37 \mathrm{mg} / \mathrm{s}$ 


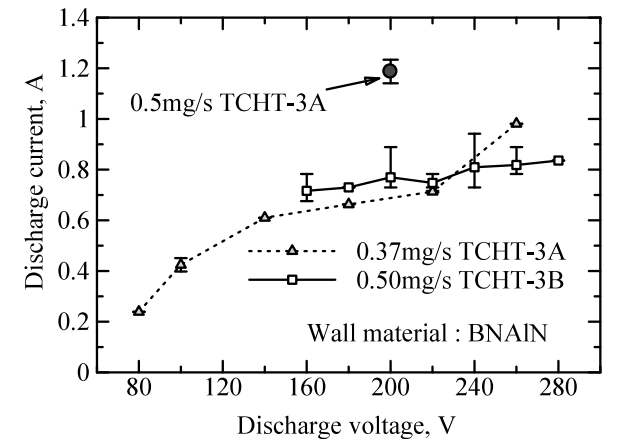

(a) 放電電流

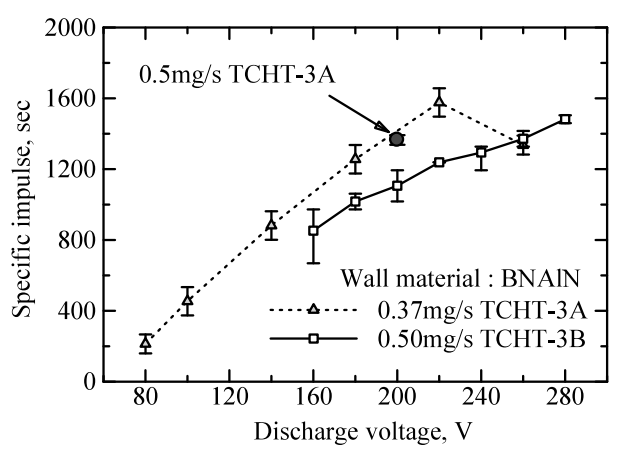

(b) 比推力

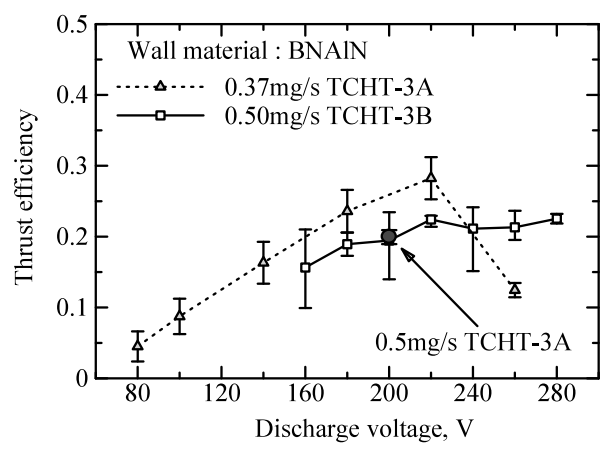

(c) 推進効率

第11図 推進特性と放電電圧の関係 (TCHT-3A と TCHT-3B と の比較, TCHT-3A の外側コイル電流 $2 \mathrm{~A}$, 推進剂流量 $0.37 \mathrm{mg} / \mathrm{s}, 0.5 \mathrm{mg} / \mathrm{s}$, 放電電圧 $80 \sim 280 \mathrm{~V}$, 放電室壁材質 : BNAlN)

の場合 , TCHT-3B では安定な作動を行うことが困難であっ た . 推進特性の放電電圧による変化を第 11 図に示す .放電 電流は第 11 図 (a) に示すように電圧の増加とともに増加す る. TCHT-3A は $260 \mathrm{~V}$ 付近で放電電流が急激に増加し作 動が不安定になった . $0.5 \mathrm{mg} / \mathrm{s}$ における TCHT-3B の放電 電流は $0.37 \mathrm{mg} / \mathrm{s}$ における TCHT-3A よりもやや大きい程 度である.乥して放電電圧 $200 \mathrm{~V}$, 流量 $0.5 \mathrm{mg} / \mathrm{s}$ において は, TCHT-3B の放電電流は TCHT-3A よりも明らかに小 さく, TCHT-3B の場合 , 放電電流は TCHT-3A に比へてて 抑えられていることがわかる.

第 11 図 (b) に比推力一放電電圧特性を示す.TCHT-3B の比推力は放電電圧 $260 \mathrm{~V}$ の場合を除き TCHT-3A と比べ て低かった . TCHT-3B の場合放電電流がさかったこと， そして $0.37 \mathrm{mg} / \mathrm{s}$ では作動が困難であったことを考慮する

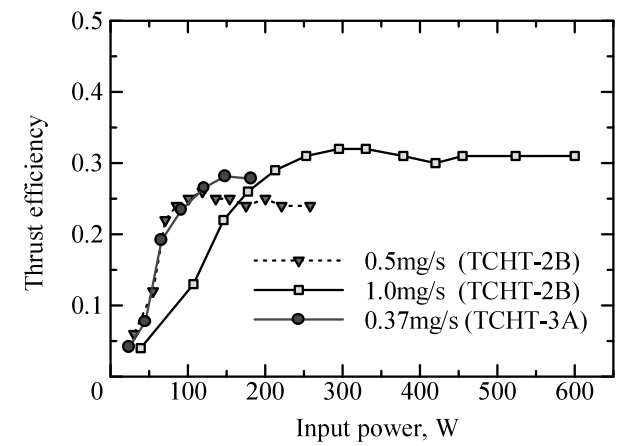

第 12 図 推進効率と投入電力の関係 (TCHT-2 と TCHT-3A との 比較)

と比推力が低下したのは推進剂利用効率の低下によるもの と考えられる . 推進剂利用効率が低下した原因は次のよう に考えられる . スラスタ下流側に強い半径方向磁場が印加 されており電離領域は下流に移動したが，ここでの中性粒 子は陽極付近に比へ拡散し关の数密度は小さくなっている。 従って電離か効率よく行われず推進剂利用効率が低下した ものと考えられる. 結果として TCHT-3B の推進性能は第 11 図 (c) に示すように TCHT-3A よりも低くなった .

3.4 投入電力による推進効率の変化 $\mathrm{TCHT}-2\left(L_{2}=\right.$ $0 \mathrm{~mm})$ およびTCHT-3A の投入電力と推進効率の関係を第 12 図に示す . 投入電力 120 $180 \mathrm{~W}$ の範囲では TCHT-3A の推進効率は TCHT-2 に比べて高く , スラスタの小型化 により推進性能を向上させることができた . TCHT-2 の 100 250 W の電力範囲における推進効率は 25 31\%で SPT-30 (同じ電力範囲で 16〜34\%) ${ }^{4}$ と同等もしくは光 れ以上の推進性能が得られた .

\section{4. 結論}

円形断面放電室をもつホールスラスタ TCHT シリーズ の性能特性か調べられた . またイオンコレクタ, RPA 及び ダブルプローブを用いてプラズマ測定，イオンビーム測定 を行った .さらに小型のスラスタを製作し，性能の変化を 調べた . 以下に得られた結果を示す .

1) TCHT-2 の実験結果から，放電室を円形断面部のみ で構成した場合 $\left(L_{2}=0 \mathrm{~mm}\right)$ も安定に作動することがわ かった．また円環状断面部をもつ場合と比べてより高い比 推力・推進効率が得られた。

2) TCHT-2 のイオン電流分布測定から $0.5 \mathrm{mg} / \mathrm{s}$ の場合 と $1.0 \mathrm{mg} / \mathrm{s}$ の場合のビーム発散角は等しいが, 算出した 推進剂利用効率は $1.0 \mathrm{mg} / \mathrm{s}$ の場合により高いことがわかっ た . RPA 測定からイオンビームのピーク及び平均エネル ギーは $0.5 \mathrm{mg} / \mathrm{s}$ の場合 $1.0 \mathrm{mg} / \mathrm{s}$ に比べて若干低いことが わかった .

3) ダブルプローブ測定より陽極付近で電子温度は高くな ることがわかった . また放電室内に印加されたノズル状磁 場の磁束が収束する箇所付近で電子数密度が増加すること がわかった .

4）より小型の TCHT-3A において V/S 比の低下による 
ものと思われる比推力・推進効率の低下が見られた .

5) TCHT-3B において下流領域に強い半径方向磁場を 形成することにより TCHT-3A に比へてて放電電流を抑える ことができた . しかし比推力 , 推進効率は TCHT-3A に比 ベて低くなった .

6) TCHT シリーズホールスラスタは電力 $100 \mathrm{~W}$ におい て約 $25 \%$ の推進効率を示し，低電力域において SPT タイ プより高い推進性能が得られることがわかった .

\section{参 考 文 献}

1) Asada, S., Abe, N., Ando, K. and Fleeter, R.: Launching Small Satellites on the H-IIA Rocket, 17th Annual AIAA/USU Conf. on Small Satellites, Paper SSC-03-II-4, 2003.

2) Tahara, H.: An Overview of Electric Propulsion Activities in Japan, 28th Int. Electric Propulsion Conf., Toulouse, IEPC Paper 03-339, 2003.

3) Khayms, V. and Martinez-Sanchez, M.: Fifty Watt Hall Thruster for Microsatellites, Micci, M. M. and Ketsdever, A. D. (eds), Micropropulsion for Small Spacecraft, Progress in Astronautics and Aeronautics, Vol. 187, 2000, Chap. 9.

4) Jacobson, D. and Jankovsky, R.: Test Results of a $200 \mathrm{~W}$ Class Hall Effect Thruster, 34th Joint Propulsion Conf.,
AIAA Paper 98-3791, 1998.

5) Zhurin, V. V., Kaufman, H. R. and Robinson, R. S.: Physics of Closed Drift Thrusters, Plasma Sources Sci. Technol., 8 (1999), pp. R1-R20.

6) Raitses, Y. and Fisch, N. J.: Parametric Investigations of a Nonconventional Hall Thruster, Phys. Plasmas, 8 (2001), pp. $2579-2586$.

7) Smirnov, A., Raitses, Y. and Fisch, N. J.: Parametric Investigation of Miniaturized Cylindrical and Annular Hall Thrusters, J. Appl. Phys., 92 (2002), pp. 5673-5679.

8) 田原弘一, 後藤大亮, 藤岡崇志, 北野貴久, 白崎篤司, 安井利明, 吉川孝雄 : 低電力ホールスラスタの基本作動特性と推進性能 , 目 本航空宇宙学会論文集 , 50 (2002), pp. 318-324.

9) Shirasaki, A., Yuge, S., Tahara, H. and Yoshikawa, T.: Operational Characteristics and Thrust Performance of Hall Thrusters with Circular Cross-Sectional Discharge Chambers, Adv. Appl. Plasma Phys., 4 (2003), pp. 121-126.

10) Shirasaki, A., Tahara, H. and Yoshikawa, T.: Operational Characteristics of Cylindrical Hall Thrusters, 28th Int. Electric Propulsion Conf., Toulouse, IEPC Paper 03-051, 2003.

11) Shirasaki, A., Tahara, H. and Yoshikawa, T.: Plasma Diagnostic Measurement of a Hall Thruster with a Circular Cross-Sectional Discharge Chambers, Proceedings of Asian Joint Conference on Propulsion and Power 2005, Kitakyushu, Paper AJCPP 2005-22071, 2005. 